demics (professors, in general), while most others will not remain as scholars in higher education. In many European countries, scholars not only run the risk of a small success rate but also have to spend many years on a short-term contract while most other professionals from the same age cohort already enjoy stable employment conditions. A study on academic careers in a number of European countries shows that employment conditions and career patterns for young academics vary substantially by country. However, short-term employment until about the age of 40 and high levels of selectivity are common in many countries

In some European countries, the situation of young academics is often deplored with the claim that the employment of young academics in the United States was far more favorable. For example, a further brain drain to the United States was anticipated by Germans if the employment conditions in Germany were not improved. A recent study, however, concluded that career conditions for young academics in Germany were not as unfavorable in comparison to the United States as public rumors suggest.

The majority of the doctoral candidates at German universi-

The majority of the doctoral candidates at German universities are employed by their university at least on a part-time temporary contract.

ties are employed by their university at least on a part-time temporary contract, and doctoral candidates have better chances than US doctoral candidates to fund their doctoral work with the help of the university or fellowships. The period from a doctoral degree to a professorial position in Germany $(8$ years, on average, from age 33 to $4 \mathrm{I}$ ) is similar to the period from a doctoral degree to the appointment as associate professor in the United States (most likely 7 years, from age 33 to 40 ). More than 30 percent of academics with a doctoral degree employed at a German higher education institution have an indeterminate work contract, but less than io percent of US assistant professors have such a status. Salaries at German institutions of higher education at all levels are on average slightly higher than at US universities.

The study shows, in addition, that about one-tenth of graduates from German institutions of higher education will eventually be awarded a doctorate, and about one-tenth of those awarded a doctorate eventually will become a professor. In the United States as well, one of about Ioo graduates will become a professor, but the levels of selection are different: one out of about 20 students will be a awarded a PhD, while one-fifth of the PhD holders eventually will become associate or full professors.

\section{The Crisis of the American Academic Workforce}

\section{Philip G. Altbach and Martin J. Finkelstein}

Philip G. Altbach is Monan professor of higher education and director of the Center for International Higher Education at Boston College. Martin J. Finkelstein is professor of higher education at Seton Hall University.

The former New York governor, Eliot Spitzer, declared the desire to improve public higher education by adding 2,000 new faculty members and creating an endowment of $\$ 4$ billion to make his state more competitive. Editorials in the New York Times and the Boston Globe agreed that higher education must be a priority for competitiveness. Nationwide, financial allocations to public higher education are up 7.5 percent, the greatest increase in a decade. The stakes are high in the knowledge economy, and higher education is central to winning. Colleges and universities train the next generation of bright entrepreneurs and scientists, generate the research that fuels the knowledge economy, and sustain local economic development.

Key to an improvement in so labor intensive an industry as higher education is its workforce: the professoriate. The American academic profession is, however, widely acknowledged to be in "critical" - and deteriorating-condition. The problem is in part demographic. The average professor is now over 50 years of age and nearly one in five over 6o. Perhaps half will be retiring in the coming decade. Many disciplines, especially in ones related to science and technology, suffer a dearth of new PhDs to fill the ranks of those who will retire or the new positions that might be added.

Another problem concerns remuneration. Academic salaries, on average, are not competitive with comparable jobs outside higher education. While the "best and the brightest" have never been lured to academe by money alone, salaries must be adequate to support a middle-class lifestyle. While a small percentage of senior professors at top universities receive six-figure salaries, the average professor earns below $\$ 70,000-$ on a par with newly graduating nurses. Salaries at the top institutions, especially the prestigious private universities, have expanded much more rapidly than those at the public colleges and universities, which 80 percent of American students attend. Even institutions like Berkeley and Wisconsin worry that they can no longer compete with the best private universities.

Many experts feel qualms about the future attractiveness of the profession. Some concerns involve a dwindling supply of qualified PhDs, the high dropout rates in doctoral programs, and lengthening time-to-degree. The Harvard-based Collaborative on Academic Careers in Higher Education sees a risk in the attrition among faculty who actually enter the aca- 
demic ranks in their early career years-similar to the "hemorrhaging" attrition among new public school teachers and nurses.

Perhaps the greatest crisis is a sea change in the nature of academic employment contracts. Traditionally, most academics were full-time on the "tenure track." They were hired fresh out of graduate school with a $\mathrm{PhD}$ as an assistant professor, and if they demonstrated adequate, and usually exemplary, performance they would be promoted to a tenured position with the expectation, with ongoing good performance, of a lifetime job. Academics earned somewhat lower salaries in order to have the security of tenure, which protects academic freedom. A reasonably robust job market assured most young scholars and scientists of a full-time tenure track appointment after completing the long grind of doctoral study. The profession attracted young people interested in "the life of the mind" to teaching and in many cases to research as well.

\section{The Deterioration of the Career}

Since 1990, less than half of the full-time faculty appointed by American colleges and universities are in probationary positions that may lead to tenure and a stable career. The majority of full-time faculty hired in the past 15 years are on annual or short-term contracts and ineligible for permanent appointments $57 \%$ in 2005, according to the National Center for Education Statistics). Indeed, an even greater number of the new generation of college faculty are hired on a part-time basis to teach a course or two with absolutely no job security or benefits. While some types of institutions and academic fields are more "at risk" than others, this phenomenon is occurring across the board.

This change is having a profound, and largely unscruti-

The American academic profession is, however, widely acknowledged to be in "critical"- and deteriorating-condition.

nized, impact on American higher education. It means that a large number of professors lack a real connection or commitment to their institutions. They do not participate in the collegial governance that has characterized American higher education for more than a century. Academic freedom is absent. The marginalized academic force does no research and has little direct contact with or responsibility for the students they teach. They are, in many ways, like the "taxicab" professors of Latin America who come to campus to teach a course or two and then leave. This situation also means that the full-time faculty, especially those who are tenured, have increased responsibility for advising students, participating in institutions' decision making, and conducting research. Professional careers are diminished by the new arrangements. America is constructing-largely below the radar screen of public officials-a two- tiered university with a small elite cadre of full-time faculty increasingly overstressed by responsibilities and a large mass of part-time and temporary workers with few benefits and tenuous connections to their jobs or institutions. Preliminary research suggests that this new edifice may be compromising the student learning experience, the functioning of academic units, and the long-term health of the national $R \& D$ enterprise.

\section{THE FUtURE}

If New York State is to succeed in its goal of strengthening public higher education, it must start with a recognition of the deterioration in the working conditions of the professoriate and the relevance of hiring full-time tenure-track faculty. If current downward trends continue, improvement will be impossible regardless of additional funding or the creation of endowments. America's professors are the crown jewels, currently tarnished, of our colleges and universities

This article appeared in the Buffalo News.

\section{Is There a Latin American University Model?}

\section{ANDRÉs BERnASCONI}

Andrés Bernasconi is associate professor and Vice-Rector for Research and Graduate Programs at Universidad Andrés Bello, Santiago, Chile. E-mail: abernasconi@unab.cl.

Dostindependence Latin American universities developed 1 during the igth and most of the 2oth century largely under the normative influence of a Latin American idea of the university institution. In the last few decades, factors both related to the development of higher education and external to it have combined to challenge the clout of that model. As a result, notwithstanding the persistence of elements of the old paradigm, the model of the Latin American university is now related chiefly to US research universities.

\section{The Shaping of the Latin American Model}

Throughout the 2oth century universities were created from scratch or revamped from colonial predecessors to lead the postindependence endeavor to create a modern nation-state. The new universities were to train the professional, secular elites, especially civil servants. These universities were called upon to serve as the state's educational arm, for the promotion of national unity and an enlightened citizenry. Professorial chairs were largely served part-time by noted members of the liberal professions, grouped in loosely formed faculties, which in turn corresponded to professional fields-typically, law, 